Tér és Társadalom 14. évf. 2000/1. 193-195. p.

Tér és Társadalom

XIV. évf. 2000 1: 193-195

\title{
KÖNYVJELZÖ
}

\section{BELUSZKY PÁL: MAGYARORSZÁG ÁLTALÁNOS FÖLDRAJZA}

\author{
Általános rész \\ (Dialóg Campus Kiadó. Budapest-Pécs 1999, 584 o.)
}

\section{RECHNITZER JÁNOS}

A kötet a Dialóg Campus Kiadó Studia Regionum sorozatában - ami egyben az MTA Regionális Kutatások Központja Területi és Települési Kutatások sorozatának 13. darabja - látott napvilágot, 1999-ben. A könyv két nagy egységből áll. Az első rész az ország településföldrajzának és településfejlödési folyamatainak történeti, alapos, egyben igényes áttekintése, míg a második rész a szerző korábban közreadott tíz jelentỏs közleményének újra kiadása. Lényegében illusztrációja az elsỏ részben közölt kutatásoknak, azok mélyebb, esettanulmány szintủ alátámasztása, kiegészítése. A szerkesztés ebben a vonatkozásban helyesen járt el, hiszen Beluszky munkáit gyakran idézzük, illetve használjuk fel az oktatáshoz, így függelékkel együtt látjuk a témakör hazai feldolgozásának jelentős darabjait.

A hazai településföldrajzban Beluszky professzor az, aki sokat és talán mindent tud a települések fejlödéséröl, azok változásának fontosabb jellemzőiről. A mú időben is jókor jelent meg, hiszen az elmúlt tíz esztendőben csak kevés kutató (Enyedi György), köztük a szerző volt az, aki kutatási energiát, kapacitásokat fordított a település- és a városhálózat fejlődési sajátosságainak vizsgálatára.

Valahogy elhanyagolta a regionális kutatás a települést, ezen belül pedig a várost. Jobban érdekelték a kutatókat a területi folyamatok általános összefüggései, az egyes területi szerveződési formák alakulása, fejlődési sajátossága (pl. kistérségek), illetve az új mesterséges térformációk, így a régiók intézményesülése, vagy éppen fejlesztésének lehetséges irányai. A másik nagy metszete a területi kutatásoknak az Európai Unió regionális politikájának mind az intézményrendszerben, mind müködésben való adaptációjára, vagy éppen a potenciális régiók gazdasági, társadalmi szerkezetének elemzésére irányult. Nos, a regionális tudomány nem foglalkozott a települési szinttel, annak változásait az átmenetben nem vizsgálta átfogóan.

A téma aktualitása nemcsak a hiányos kutatásokban rejlik, hanem abban is, hogy az európai regionális fejlesztés új irányaiban (ESDP) jelentős hangsúlyt kap, sőt alapvető fejlesztési iránnyá válik a települési szint, különösen a város, mint a területi szerveződés csomópontja, az ismeretek, a tudás, a technológia, s ezáltal az innovációk meghatározó közvetítöje. A városok funkcióinak megváltozása, a városhálózatok kialakulása, a város és a vidék új feladatmegosztása, a városi belső 
szerkezetek megújításának szükségletei, vagy éppen kulturális, társadalmi értékek megóvása hangsúlyozott feladata lesz a következö évtizedek területi politikájának, így felértékelödik a település, $\mathrm{s}$ azon belül maga a város. Nem hanyagolhatjuk el tehát a hazai településkutatást, nem feledkezhetünk meg a csomópontok, a városok átalakulásának nyomon követéséről, a folyamatok regisztrálásáról, a sajátosságok kimutatásáról. Beluszky professzor mủve ehhez nyújt hiảnypótló eligazítást.

A kötet számtalan érdekességéből és szakmai finomságából, hatalmas ismerettárából csak két - egy kedvezö és egy kedvezőtlen - meglátásunkat emeljük ki. Az első, a hazai településföldrajz klasszikus (Princz, Mendöl, Teleki) irányzatainak, azok kutatási módszertanának (történetiség, jellemzők komplex bemutatása, a típusok regionális sajátosságainak bemutatása) folytatása, részben megújítása a könyv. Két fejezete (A településhálózat formálódása a feudalizmuskori Magyarországon; A településállomány formálódása a polgári korszakban) a klasszikus településföldrajz hagyományainak frappáns, de aktualizált és megújított folytatása. Ebből a kettőszáz (a tartalomjegyzék szerint sajnos csak hetven) oldalból mindent megtudhatunk a hazai településállomány fejlődéséről. Sỏt meg is kell tudnunk, hiszen a szerző alapvető szemlélete, hogy a településrendszerben a struktúrák éppen a múlt folyamatai következtében determináltak, azaz nem érthetjük meg a meg a közelmúltat vagy éppen a jelent ezen összefüggések nélkül. Ennek a közelmúltnak és jelennek a szerző további kétszáz oldalt szán (szemben a tartalomjegyzékkel, ahol ennél jóval több oldalt mérnek). Alaposan feltárulnak a nehéz évtizedek (államszocializmus) település alakító folyamatai, majd a rendszerváltozás utáni gazdasági és a társadalmi változások települési sajátosságai.

A másik metszet már bírálat. A könyv mindent elmond a településhálózat hazai összefüggéseiröl, azonban semmit nem közöl arról, hogy mindegyik nagy időszakban a hazai trendek miként igazodtak az európai vagy netán a közép-európai településfejlödési irányokhoz. Nem is a régmúlttal vannak gondjaink, hanem az elmúlt tíz esztendővel, azzal, hogy a magyar településhálózat és annak csomóponti elemei ugyanazon az átalakulási folyamaton mentek keresztül, mint a többi átmeneti ország centrumai, vagy vannak különbségek, azaz miként határozhatjuk meg ennek az időszaknak a másságait, lehetséges törvényszerüségeit. Továbbá a könyvben a hagyományos települési funkciók, így az intézményrendszer, a felszereltség nagy hangsúlyt kapnak, holott véleményünk szerint a településhálózat strukturálást az elmúlt években már nem ezek a tényezők alakítják, hanem a gazdasági szerepek, a fogyasztás és a piac tényezöi, illetve a mindezeket megtestesitő szervezetek jelenléte. Ezeknek az új, funkciót alakító egységeknek a telepítése már nem a centrumtól (kormányzat) függnek, hanem a regionális potenciáloktól (pl. elérhetőség), a lokális adottságoktól (pl. helyi gazdasági bázis, menedzsment, fejlesztési elképzelések, új erőforrások stb.). A szerző hatalmas adatbázissal dolgozott, melynek a kezelése számos esetben meggyőzőbb lett volna, ha azokat komplexebb módszerekkel dolgozza fel, azaz törekszik a változók belsö kapcsolatainak mélyebb, s nem csak logikai bizonyítására. Ennek hiányában több megállapítása, rendszerezése ugyan 
nagyon látványos, hatalmas ismeretanyaggal kerül alátámasztásra, de nem kellỏen egzakt.

A könyv szép megjelenésü, de szerkesztésében kimondottan zavaró elem, hogy a tartalomjegyzék nem egyezik meg a belsỏ tartalommal, így annak alapján nem tudunk eligazodni. Nem egyeznek meg a részfejezetek jelzései a szövegben a tartalomjegyzékkel. A kiadó nehezen birkózott meg a nagy terjedelmü könyvvel, jelzi ezt a tartalomjegyzéken túl az is, hogy a főszövegben lévő 132 ábra közül csak néhánynál lehet azt tudni, hogy azok honnan származnak, nincsenek jelölve a források, vagy éppen a szerző saját szerkesztése. A bőséges jegyzetállomány és irodalomjegyzék alapos áttekintést nyújt a témához, kár, hogy a kiadó vagy éppen a kiadás helye hiányzik számos esetben, azaz bibliográfiai szempontból egyenetlen a jegyzék.

Beluszky Pál könyve fontos állomása a hazai településföldrajznak, illetve a regionális tudomány településsel foglalkozó kutatásainak. Érdemes és hasznos kutatónak éppen úgy kézbe venni, mint a regionális és települési folyamatokkal foglalkozó elemzőnek, politikusnak, fejlesztőnek, de a geográfus oktatásban, vagy a regionális szakemberek képzésében is eredményesen használható. 